\title{
Sire effects on carcass and meat quality traits of young Nellore bulls
}

\author{
M.N. Bonin'1, J.B.S. Ferraz ${ }^{1}$, J.P. Eler ${ }^{1}$, F.M. Rezende ${ }^{1}$, D.C. Cucco ${ }^{2}$, \\ M.E. Carvalho ${ }^{3}$, R.C.G. Silva ${ }^{1}$, R.C. Gomes ${ }^{4}$ and E.C.M. Oliveira ${ }^{1}$ \\ ${ }^{1}$ Grupo de Melhoramento Animal e Biotecnologia, \\ Departamento de Ciências Básicas, \\ Faculdade de Zootecnia e Engenharia de Alimentos, \\ Universidade de São Paulo, Pirassununga, SP, Brasil \\ ${ }^{2}$ Departamento de Zootecnia, Universidade do Estado de Santa Catarina, \\ Chapecó, SC, Brasil \\ ${ }^{3}$ Departamento de Zootecnia, Escola Superior de Agricultura "Luiz de Queiróz", \\ Universidade de São Paulo, Piracicaba, SP, Brasil \\ ${ }^{4}$ Centro Nacional de Pesquisa de Gado de Corte, \\ Empresa Brasileira de Pesquisa Agropecuária, Campo Grande, MS, Brasil
}

Corresponding author: M.N. Bonin

E-mail: marinabonin@hotmail.com

Genet. Mol. Res. 13 (2): 3250-3264 (2014)

Received March 15, 2013

Accepted October 31, 2013

Published April 29, 2014

DOI http://dx.doi.org/10.4238/2014.April.29.3

\begin{abstract}
Meat quality is being increasingly demanded by consumers in recent years. Several factors can affect meat quality, ranging from animal traits such as breed and genetic heritage to pre- and post-slaughter processes. This study investigated the influence of Nellore bulls on carcass and meat quality traits. We used 475 young uncastrated males, the progeny of 54 bulls, to evaluate characteristics of the following carcass traits: hot carcass weight, rib-eye area, and fat thickness. We also evaluated the following beef quality traits: marbling, color, drip loss, cooking loss, and shear force at 0,7 , and 14 days of aging. Bulls had a significant influence $(\mathrm{P} \leq 0.05)$ on rib-eye area, fat thickness, marbling, drip loss at 14 days of aging and color at all aging periods. Based on these results, the use of bulls with high breeding values for these traits can
\end{abstract}


provide important advances in carcass traits and meat quality in breeding programs of Nellore cattle that are raised in tropical conditions.

Key words: Bos indicus; Color; Fat thickness; Marbling; Rib-eye area; Shear force

\section{INTRODUCTION}

Beef consumers consider product quality to be a decisive factor in their purchase decision, especially in institutional markets in the service sector. This quality standard can be defined as an interaction between color, visual appearance, tenderness, juiciness, and flavor of the meat, and tenderness stands out as the main trait. Several factors can affect meat quality, including genetics, breed, sex, age, management, feeding systems, and pre- and post-slaughter processes; therefore, the proper handling of these factors results in the production of high-quality beef. The genetic selection of animals helps in this process, either by choosing breeds that best suit production and market conditions or by selecting animals with genetic potential for the production of quality meat.

Nellore (Bos indicus) cattle produce less tender meat than Bos taurus. Differences in the physiological, biochemical, and genetic factors that are responsible for this variability (Wheeler et al., 1990; Koohmaraie, 1996) have been the subject of research for several years. Some authors argue that increasing the percentage of $B$. indicus in breeding programs decreases tenderness and increases the variability of this trait (Wheeler et al., 1990). This variability can be attributed to the heterotic effects that are achieved in breeding and to the variation between bulls of the same breed regarding the genetic potential to produce tender meat. According to Van Vleck et al. (1992), bulls of the same breed, when classified in terms of major differences, may have greater variability than bulls of different breeds. Thus, greater additive variability in traits of marbling (MAR), rib-eye area (REA), fat thickness (FT), and tenderness is expected in Zebu cattle, indicating the importance of selecting bulls within breeds for the production of meat quality.

Brazil currently accounts for one third of global beef exports (Ferraz and Felício, 2010). Production is based on livestock grazing, and $90 \%$ of the Brazilian livestock consists of Nellore cattle (ABIEC, 2012). Moreover, livestock of B. indicus in South America, Asia, and Africa account for roughly $40 \%$ of the world livestock of beef cattle (USDA, 2011). Therefore, strategies for genetically improving the meat quality of the Nellore breed can bring positive impacts to the standardization and quality of the Brazilian beef that is marketed worldwide.

In this study, we investigated the variability of carcass traits and meat quality among Nellore sires, giving subsidies to new research in this field and encouraging the selection of traits that play an important role so that Brazil can maintain the position that it earned in foreign markets and to conquer markets that are more demanding by aggregating higher value in Brazilian beef.

\section{MATERIAL AND METHODS}

\section{Population}

We evaluated 54 Nellore bulls with a minimum of three progenies (Table 1), totaling 475 young Nellore uncastrated male progeny, which were aged between 21 and 28 months, of the 2004 season. We evaluated the animals for traits of growth; reproduction; visual scores of 
conformation, precocity, and muscularity; and candidates for the Special Certificate of Identification and Production (CEIP) of the Brazilian Ministry of Agriculture, Livestock and Supply, under Decree No. 267 of May 4, 1995 (DORFB, 1995) belonging to Agro-Pecuária CFM Ltda., which is located in the municipality of Magda, São Paulo, Brazil.

Until 18 months of age, the animals were kept in a pasture, and then they were placed in a feedlot and fed with a diet consisting of $70 \%$ corn silage and $30 \%$ concentrate with $13 \%$ crude protein in the diet. The expected average daily gain was $1.3 \mathrm{~kg} \cdot$ animal $^{-1} \cdot$ day $^{-1}$. In the feedlot, the animals were divided into homogeneous lots for weight and sent for slaughter when they reached an average body weight of $550 \mathrm{~kg}$.

The animals were slaughtered in six lots on August 22, August 29, September 13, October 17, November 1, and November 8/11, 2006, and were considered as contemporary groups in this study. We scheduled the slaughters for the morning, in the first batch, after an average fasting period of $12 \mathrm{~h}$ with access to only water in the slaughterhouse waiting pens.

The distribution of sires and parents of animals that were slaughtered in relation to the number of progeny is presented in Table 1.

\section{Table 1. Description of the number of progenies per sire.}

\begin{tabular}{|c|c|c|c|c|c|c|c|c|c|c|c|c|c|c|c|}
\hline & \multicolumn{15}{|c|}{ Number of progenies } \\
\hline & 3 & 4 & 5 & 6 & 7 & 8 & 9 & 11 & 12 & 16 & 17 & 27 & 28 & 46 & 51 \\
\hline \multirow[t]{13}{*}{ Sires } & 8 & 2 & 15 & 11 & 3 & 22 & 4 & 5 & 34 & 12 & 16 & 18 & 28 & 1 & 54 \\
\hline & 10 & 7 & 24 & 13 & 9 & & 37 & 6 & & & 31 & & & & \\
\hline & 25 & 17 & 27 & 20 & 14 & & 40 & 43 & & & & & & & \\
\hline & 32 & 19 & 35 & 33 & 26 & & 48 & & & & & & & & \\
\hline & 39 & 21 & 41 & 38 & 36 & & & & & & & & & & \\
\hline & 44 & 23 & & 51 & 52 & & & & & & & & & & \\
\hline & 45 & 29 & & & & & & & & & & & & & \\
\hline & 46 & 30 & & & & & & & & & & & & & \\
\hline & & 42 & & & & & & & & & & & & & \\
\hline & & 47 & & & & & & & & & & & & & \\
\hline & & 49 & & & & & & & & & & & & & \\
\hline & & 50 & & & & & & & & & & & & & \\
\hline & & 53 & & & & & & & & & & & & & \\
\hline
\end{tabular}

\section{Carcass traits}

At slaughter, we collected the individual identification numbers of animals, and individual identification labels were affixed with the slaughter order number to the left side of each carcass. After slaughter, the carcasses were sawed in half lengthwise, weighed to obtain the hot carcass weight $(\mathrm{HCW})$, and cooled to $2^{\circ} \mathrm{C}$ for $24 \mathrm{~h}$. After the $24 \mathrm{~h}$ of cooling, we measured the longissimus muscle $\mathrm{pH}(\mathrm{pH} 24)$. In this same period, the left side of each carcass was sawed at the 12th and 13th ribs to measure the REA, FT, and MAR of the longissimus muscle. To measure REA, we used a square grid that was transparent and subdivided into $\mathrm{cm}^{2}$ units on the muscle to determine the area in $\mathrm{cm}^{2}$. To measure FT, we used a ruler that was graduated in millimeters.

\section{Meat quality}

To analyze MAR, we used the United States Department of Agriculture's quality grade with six scales that started with "slight" (less marbled meat) and went up to "moderately 
abundant" (more marbled meat), which were converted into numerical values starting at 400 points (slight) and went up to 900 points (moderately abundant) for the statistical analysis.

To analyze color, dripping loss (DL), cooking losses (CL), and shear force (SF), we collected three samples of the longissimus muscle at the 12th, 11th, and 10th ribs that were $2.5 \mathrm{~cm}$ thick for aging for 7, 14, and 21 days, respectively. The samples were then identified, vacuum packaged, and stored during the respective periods in a maturation chamber at $2^{\circ} \mathrm{C}$.

For the color analysis, we removed the samples from the packages, placed them on aluminum trays, and exposed them to ambient temperature $\left(18^{\circ} \mathrm{C}\right)$ to oxygenate the surface for 20 $\mathrm{min}$. The sample color was determined by the average of three measurements at different points of each sample using a portable colorimeter model MiniScan XE, brand Hunter Lab, with a light source D65, an observation angle of 10 degrees, and a cell opening of $30 \mathrm{~mm}$. We used the scale $\mathrm{L}^{*}, \mathrm{a}^{*}, \mathrm{~b}^{*}$ of the CIELab system, where $\mathrm{L}^{*}$ is the chroma associated with light $\left(\mathrm{L}^{*}=0\right.$ is black; $\mathrm{L}^{*}=100$ is white), $\mathrm{a}^{*}$ is the chroma varying from green $(-)$ to red $(+)$; and $\mathrm{b}^{*}$ varies from blue $(-)$ to yellow $(+)$. From the values of $\mathrm{a}^{*}$ and $\mathrm{b}^{*}$, we calculated values of chroma $\left(\mathrm{C}^{*}\right)$ (Equation 1) which, according to Hunt et al. (1991), is the intensity of one color, i.e., the quality that can distinguish dark and light colors, which is also known as the color saturation degree. We also used hue $\left(\mathrm{H}^{*}\right)$ as a variable to distinguish names and families of colors and the result of the pulse differences and wavelengths that produce the color sensation in the retina (Equation 2):

$$
\begin{array}{cc}
C^{*}=\sqrt{\left(\left(a^{*}\right)^{2}+\left(b^{*}\right)^{2}\right)} & \text { (Equation 1) } \\
H^{*}=\tan ^{-1}\left(\frac{b^{*}}{a^{*}}\right) & \text { (Equation 2) }
\end{array}
$$

where: $\mathrm{a}^{*}$ : chroma varying from green (-) to red (+); $\mathrm{b}^{*}$ : chroma varying from blue (-) to yellow $(+)$; tan = tangent; $\mathrm{C}^{*}=$ chroma; $\mathrm{H}^{*}=$ hue.

Analyses of DL, CL, and SF were performed following the standards recommended by AMSA (1995). Cooked samples were used to determine the SF, where after measuring the sample temperature (TSS), we obtained eight cylindrical sub-samples of $1.27 \mathrm{~cm}(1 / 2 \mathrm{inch})$ in diameter using an electrical drill adapted with metal punches to remove the cylinders (Kastner and Henrickson, 1969). The SF was measured in a Warner Bratzler Shear Force mechanical device with a $25-\mathrm{kg}$ capacity and a shearing speed of $20 \mathrm{~cm} / \mathrm{min}$. The $\mathrm{SF}$ value of each sample was represented by the arithmetic mean of the SF values obtained from the eight sub-samples.

\section{Statistical analysis}

To analyze the bull effect, data on carcass and meat quality of animals of unknown parents, progenies of the plot with multiple reproducers, and bulls with fewer than three progenies were disregarded. Thus, the database that was used to check the variability among bulls in the traits studied consisted of 475 animals.

The statistical model that was used to detect variability among traits of the bulls considered a structure with half-sibs from a paternal bull as a random effect in addition to the fixed effects that are described in Table 2. This allowed us to estimate (co)variance components 
associated with the bull effect. We tested the estimated value of the bull contribution using PROC MIXED of the SAS statistical package (SAS Institute Inc., 2003) at a significance level of $5 \%$ as shown in Equation 3.

$$
Y_{i j k}=\mu+S B_{i}+\beta_{p}\left(W_{i j k}-\bar{W}_{p}\right)+S_{j}+e_{i j k} \quad(\text { Equation 3) }
$$

where $Y_{i j k}=$ phenotypic value observed for the traits related to carcass and meat quality; $\mu=$ constant inherent to all observations; $S B_{i}=$ fixed effect of slaughter batch; $p=1,2,3$, and 4, corresponding to age at slaughter, $\mathrm{pH}, \mathrm{FT}$, and TSS; $\beta_{p}=$ linear regression coefficients of the $Y_{i j k}$ trait in relation to covariate $p ; W_{i j k}=$ animal's value for the covariate $p ; W=$ mean of covariate $p$ for all animals evaluated; $S_{j}=$ random effect of sire, with $\mathrm{N}\left(0, \sigma_{\mathrm{e}}^{2}\right) ; e_{i j k}$ is the residual random term, assumed $\mathrm{N}\left(0, \sigma_{\mathrm{e}}^{2}\right)$.

Table 2. Factors used in the models for assessing variability among sires on $\mathrm{HCW}=$ hot carcass weight; $\mathrm{REA}=$ rib-eye area; $\mathrm{FT}=$ fat thickness; $\mathrm{MAR}=$ marbling; $\mathrm{DL}=$ drip loss; $\mathrm{CL}=$ cooking loss; $\mathrm{SF}=$ shear force; values of $\mathrm{L}^{*}$ (light), $\mathrm{C}^{*}$ (chroma) and $\mathrm{H}^{*}$ (hue) at 7, 14 and 21 days of aging.

\begin{tabular}{|c|c|c|c|c|c|}
\hline \multirow[t]{2}{*}{ Traits } & \multirow{2}{*}{$\frac{\text { Fixed effect }}{\text { Slaughter batch }}$} & \multicolumn{4}{|c|}{ Covariates } \\
\hline & & Age at slaughter & $\mathrm{pH} 24$ & Fat thickness & Temperature at shearing the samples \\
\hline $\mathrm{HCW}$ & $\mathrm{x}$ & $\mathrm{x}$ & & & \\
\hline REA & $\mathrm{x}$ & $\mathrm{x}$ & & & \\
\hline FT & $\mathrm{x}$ & $\mathrm{x}$ & & & \\
\hline MAR & $\mathrm{x}$ & $\mathrm{x}$ & & & \\
\hline DL7 & $\mathrm{x}$ & $\mathrm{x}$ & $\mathrm{x}$ & $\mathrm{x}$ & \\
\hline DL14 & $\mathrm{x}$ & $\mathrm{x}$ & $\mathrm{x}$ & $\mathrm{x}$ & \\
\hline DL21 & $\mathrm{x}$ & $\mathrm{x}$ & $\mathrm{x}$ & $\mathrm{x}$ & \\
\hline CL7 & $\mathrm{x}$ & $\mathrm{x}$ & $\mathrm{x}$ & $\mathrm{x}$ & \\
\hline CL14 & $\mathrm{x}$ & $\mathrm{x}$ & $\mathrm{x}$ & $\mathrm{x}$ & \\
\hline CL21 & $\mathrm{x}$ & $\mathrm{x}$ & $\mathrm{x}$ & $\mathrm{x}$ & \\
\hline SF7 & $\mathrm{x}$ & $\mathrm{x}$ & $\mathrm{x}$ & $\mathrm{x}$ & $\mathrm{x}$ \\
\hline SF14 & $\mathrm{x}$ & $\mathrm{x}$ & $\mathrm{x}$ & $\mathrm{x}$ & $\mathrm{x}$ \\
\hline SF21 & $\mathrm{x}$ & $\mathrm{x}$ & $\mathrm{x}$ & $\mathrm{x}$ & $\mathrm{x}$ \\
\hline L"7 & $\mathrm{x}$ & $\mathrm{x}$ & $\mathrm{x}$ & $\mathrm{x}$ & \\
\hline $\mathrm{L}^{*} 14$ & $\mathrm{x}$ & $\mathrm{x}$ & $\mathrm{x}$ & $\mathrm{x}$ & \\
\hline L"21 & $\mathrm{x}$ & $\mathrm{x}$ & $\mathrm{x}$ & $\mathrm{x}$ & \\
\hline $\mathrm{C}^{*} 7$ & $\mathrm{x}$ & $\mathrm{x}$ & $\mathrm{x}$ & $\mathrm{x}$ & \\
\hline $\mathrm{C}^{*} 14$ & $\mathrm{x}$ & $\mathrm{x}$ & $\mathrm{x}$ & $\mathrm{x}$ & \\
\hline $\mathrm{C}^{*} 21$ & $\mathrm{x}$ & $\mathrm{x}$ & $\mathrm{x}$ & $\mathrm{x}$ & \\
\hline $\mathrm{H}^{*} 7$ & $\mathrm{x}$ & $\mathrm{x}$ & $\mathrm{x}$ & $\mathrm{x}$ & \\
\hline $\mathrm{H}^{*} 14$ & $\mathrm{x}$ & $\mathrm{x}$ & $\mathrm{x}$ & $\mathrm{x}$ & \\
\hline $\mathrm{H}^{*} 21$ & $\mathrm{x}$ & $\mathrm{x}$ & $\mathrm{x}$ & $\mathrm{x}$ & \\
\hline
\end{tabular}

\section{RESULTS AND DISCUSSION}

The descriptive statistics of the traits analyzed are shown in Table 3. The P values for the traits evaluated in this study are shown in Table 4 . We found a sire effect $(\mathrm{P} \leq 0.05)$ on REA, FT, MAR, DL14, L*, and $\mathrm{H}^{*}$ at 7, 14, and 21 days of aging. The FT linearly influenced the traits of MAR, SF7, SF14, DL14, and L* $14(\mathrm{P}<0.05)$. All traits evaluated in this study, except CL7 and CL14, had a slaughter batch $(\mathrm{SB})$ effect $(\mathrm{P}<0.05)$. The age at slaughter (AGE) had a linear effect only on the MAR trait $(\mathrm{P}<0.05)$. The $\mathrm{pH}$ showed a linear relationship $(\mathrm{P}>0.05)$ with all traits except SF14, SF21, DL14, CL7, and $\mathrm{H}^{*} 21$. The TSS had no effect on $\mathrm{SF}$ in any aging period $(\mathrm{P}>0.05)$. 
Table 3. Descriptive statistics of the trait of slaughter age (AGE), $\mathrm{pH}$ at $24 \mathrm{~h}$ of cooling (pH24), hot carcass weight (HCW), rib-eye area (REA) and fat thickness (FT), marbling (MAR), drip loss (DL), cooking loss (CL), shear force (SF), light $\left(\mathrm{L}^{*}\right)$, chroma $\left(\mathrm{C}^{*}\right)$ and hue $\left(\mathrm{H}^{*}\right)$ at 7,14 and 21 days of aging measured in Nellore young bulls.

\begin{tabular}{|c|c|c|c|c|c|}
\hline Traits & $\mathrm{N}$ & Average & Min & Max & SD \\
\hline AGE (days) & 466 & 738.14 & 656.00 & 826.00 & 36.90 \\
\hline pH24 & 446 & 5.92 & 5.48 & 6.45 & 0.19 \\
\hline $\mathrm{HCW}(\mathrm{kg})$ & 449 & 288.99 & 261.50 & 325.50 & 13.04 \\
\hline $\operatorname{REA}\left(\mathrm{cm}^{2}\right)$ & 462 & 58.00 & 90.00 & 40.28 & 6.35 \\
\hline $\mathrm{FT}(\mathrm{mm})$ & 466 & 4.32 & 1.00 & 9.00 & 1.80 \\
\hline MAR (units) & 474 & 427.06 & 400.00 & 600.00 & 42.48 \\
\hline SF7 (kg) & 462 & 5.99 & 1.64 & 10.90 & 1.40 \\
\hline SF14 (kg) & 463 & 4.95 & 1.45 & 9.65 & 2.83 \\
\hline SF21 (kg) & 467 & 4.35 & 1.53 & 8.70 & 1.07 \\
\hline DL7 $(\%)$ & 419 & 2.80 & 0.18 & 6.11 & 1.23 \\
\hline DL14 (\%) & 428 & 3.70 & 0.41 & 7.70 & 1.51 \\
\hline DL21 (\%) & 420 & 4.50 & 0.84 & 8.53 & 1.50 \\
\hline CL7 (\%) & 443 & 12.15 & 3.85 & 20.13 & 3.20 \\
\hline CL14 (\%) & 457 & 10.83 & 3.88 & 18.00 & 2.84 \\
\hline CL21 (\%) & 455 & 10.72 & 1.98 & 18.18 & 3.21 \\
\hline $\mathrm{L} * 7$ & 463 & 37.83 & 30.86 & 44.89 & 2.91 \\
\hline $\mathrm{L} * 14$ & 463 & 37.92 & 29.00 & 45.48 & 3.44 \\
\hline $\mathrm{L} * 21$ & 458 & 38.73 & 31.21 & 46.15 & 2.82 \\
\hline $\mathrm{C} * 7$ & 460 & 20.94 & 14.66 & 25.37 & 2.36 \\
\hline$C^{*} 14$ & 458 & 21.62 & 13.32 & 28.13 & 3.00 \\
\hline$C * 21$ & 449 & 22.82 & 17.12 & 26.89 & 1.97 \\
\hline $\mathrm{H}^{* 7}$ & 460 & 40.08 & 34.01 & 45.72 & 1.99 \\
\hline $\mathrm{H}^{*} 14$ & 458 & 39.64 & 27.95 & 47.26 & 2.80 \\
\hline $\mathrm{H}^{*} 21$ & 449 & 40.52 & 35.17 & 48.11 & 1.97 \\
\hline
\end{tabular}

$\mathrm{N}=$ number of observations; $\mathrm{Min}=$ minimum value found in each trait; $\mathrm{Max}=$ maximum value found in each trait; $\mathrm{SD}=$ standard deviation.

Table 4. $\mathrm{P}$ values that describe the level of statistical significance at $5 \%\left(^{\dagger}\right)$; effects of slaughter batch, slaughter age (AGE), $\mathrm{pH}$ at $24 \mathrm{~h}$ of cooling (pH24), fat thickness (FT), temperature before shearing samples (TSS).

\begin{tabular}{|c|c|c|c|c|c|c|}
\hline \multirow[t]{2}{*}{ Traits } & \multicolumn{6}{|c|}{ Effects } \\
\hline & Sire & SB & AGE & $\mathrm{pH} 24$ & FT & TSS \\
\hline $\mathrm{HCW}$ & 0.1918 & $<0.0001^{\dagger}$ & 0.1187 & - & - & - \\
\hline pH24 & 0.6000 & $<0.0001^{\dagger}$ & 0.7690 & - & 0.9514 & - \\
\hline REA & $0.0507^{\dagger}$ & $<0.0001^{\dagger}$ & 0.6592 & - & - & - \\
\hline FT & $<0.0001^{\dagger}$ & $0.0002^{\dagger}$ & 0.7837 & - & - & - \\
\hline MAR & $0.0263^{\dagger}$ & $<0.0001^{\dagger}$ & $0.0151^{\dagger}$ & - & $<0.0001^{\dagger}$ & - \\
\hline SF7 & 0.1471 & $0.0366^{\dagger}$ & 0.4925 & $0.0537^{\dagger}$ & $0.0149^{\dagger}$ & 0.9717 \\
\hline SF14 & 0.0644 & $<0.0001^{\dagger}$ & 0.6741 & 0.0775 & $0.0359^{\dagger}$ & 0.7631 \\
\hline SF21 & 0.1814 & $0.0040^{\dagger}$ & 0.2153 & 0.1507 & 0.7054 & 0.1997 \\
\hline DL7 & 0.6259 & $<0.0001^{\dagger}$ & 0.7569 & $0.0150^{\dagger}$ & 0.7558 & - \\
\hline DL14 & $0.0014^{\dagger}$ & $<0.0001^{\dagger}$ & 0.1828 & 0.1616 & $0.0195^{\dagger}$ & - \\
\hline DL21 & 0.1386 & $<0.0001^{\dagger}$ & 0.1277 & $0.0009^{\dagger}$ & 0.1283 & - \\
\hline CL7 & 0.6843 & 0.6878 & 0.8524 & 0.1366 & 0.6185 & - \\
\hline CL14 & 0.5371 & 0.0866 & 0.9729 & $0.0422^{\dagger}$ & 0.8369 & - \\
\hline CL21 & 0.1918 & $<0.0001^{\dagger}$ & 0.2721 & $0.0223^{\dagger}$ & 0.4036 & - \\
\hline $\mathrm{L} * 7$ & $0.0037^{\dagger}$ & $<0.0001^{\dagger}$ & 0.8526 & $0.0021^{\dagger}$ & 0.8594 & - \\
\hline L*14 & $0.0015^{\dagger}$ & $<0.0001^{\dagger}$ & 0.6131 & $0.0005^{\dagger}$ & $0.0591^{\dagger}$ & - \\
\hline $\mathrm{L} * 21$ & $0.0457^{\dagger}$ & $<0.0001^{\dagger}$ & 0.6749 & $0.0076^{\dagger}$ & 0.5373 & - \\
\hline$C^{* 7}$ & 0.8093 & $<0.0001^{\dagger}$ & 0.6378 & $<0.0001^{\dagger}$ & 0.8228 & - \\
\hline C*14 & 0.4205 & $<0.0001^{\dagger}$ & 0.6686 & $<0.0001^{\dagger}$ & 0.3618 & - \\
\hline C*21 & 0.1109 & $0.0013^{\dagger}$ & 0.5653 & $<0.0001^{\dagger}$ & 0.9195 & - \\
\hline $\mathrm{H}^{* 7}$ & $0.0028^{\dagger}$ & $<0.0001^{\dagger}$ & 0.5192 & $0.0081^{\dagger}$ & 0.2345 & - \\
\hline $\mathrm{H}^{*} 14$ & $0.0235^{\dagger}$ & $<0.0001^{\dagger}$ & 0.7079 & $0.0305^{\dagger}$ & 0.1310 & - \\
\hline $\mathrm{H}^{*} 21$ & $0.0020^{\dagger}$ & $<0.0001^{\dagger}$ & 0.2964 & 0.0711 & 0.6425 & - \\
\hline
\end{tabular}

$\mathrm{HCW}=$ hot carcass weight; $\mathrm{pH} 24=\mathrm{pH}$ at $24 \mathrm{~h}$ of cooling; $\mathrm{REA}=$ rib-eye area; $\mathrm{MAR}=$ marbling; $\mathrm{SF}=$ shear force; $\mathrm{DL}=$ drip loss; $\mathrm{CL}=$ cooking loss; light $\left(\mathrm{L}^{*}\right)$, chroma $\left(\mathrm{C}^{*}\right)$, and hue $\left(\mathrm{H}^{*}\right)$ at 7,14 and 21 days of aging. 
As shown in Table 4, the SB had an effect on all traits in this study except CL7 and CL14. These results highlight the importance of controlling SB, given that pre- and postslaughter procedures can greatly influence meat quality traits such as $\mathrm{pH}$, tenderness, and meat color. In addition, SB were formed as the animals reached the slaughter weight that was determined by the enterprise, which may also explain the influence of the slaughter batch effect on HCW, FT, and MAR.

\section{HCW and REA}

We did not find any sire effect on HCW ( $\mathrm{P}>0.05)$; there was a 4.09-kg difference between the extreme values of this trait (Figure 1). Although differences among sires were not statistically significant, these differences may be important. Because of the volume of animals that are slaughtered in Brazil (28.9 million; IBGE, 2012), bulls with a 2-kg difference in carcass/progeny would represent an increase of 57.8 million kilograms of hot carcass to domestic production, which equates to $1 \%$ and is highly relevant.

We detected great variability among Nellore sires regarding the genetic potential to produce progeny with high REA; we observed a difference of $3.68 \mathrm{~cm}^{2}$ between bulls that had extreme values of this trait (Figure 2). Thus, the superiority of some Nellore sires to produce progeny with higher yields of prime cuts in the carcass is evident. According to Hamlin et al. (1995), REA measurements can be used as indicators of carcass composition and may indicate animals with high genetic potential for carcass production with greater cut yield and consequently higher commercial value.

Sainz et al. (2005) also found quantitative and qualitative variations in Nellore carcasses and attributed these changes to genetic differences between bulls of this breed. In this sense, Burrow et al. (2001) stated that differences in meat quality attributes of $B$. indicus can lead to genetic selection within breeds because of seeking animals that are genetically superior and best suited for economically viable production systems and meat supply with commercially desirable quality standards.

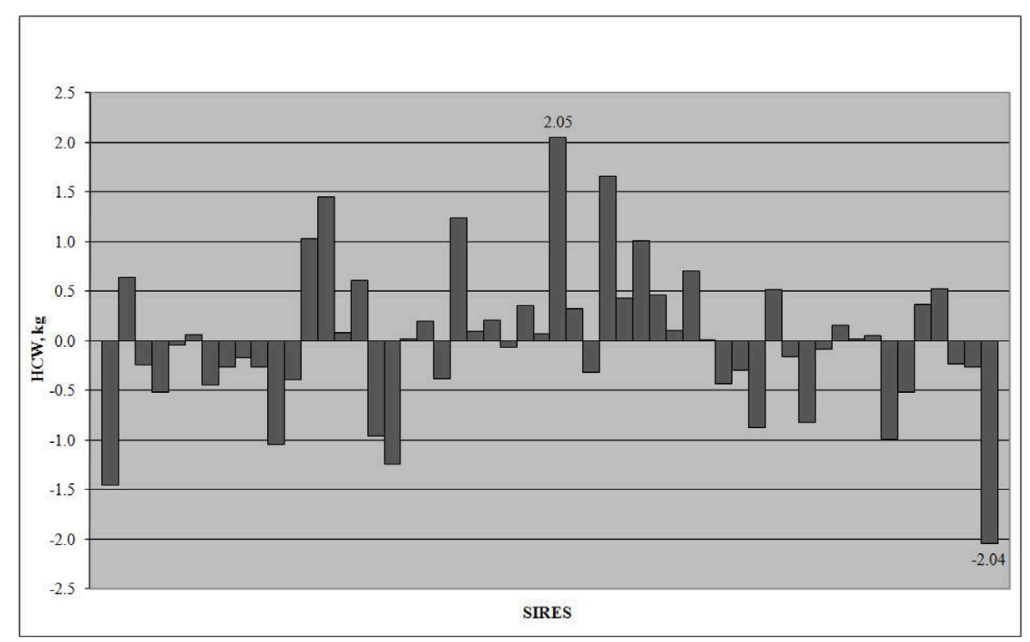

Figure 1. Graphical representation of hot carcass weight $(\mathrm{HCW})$ values in terms of least square means of sires. 


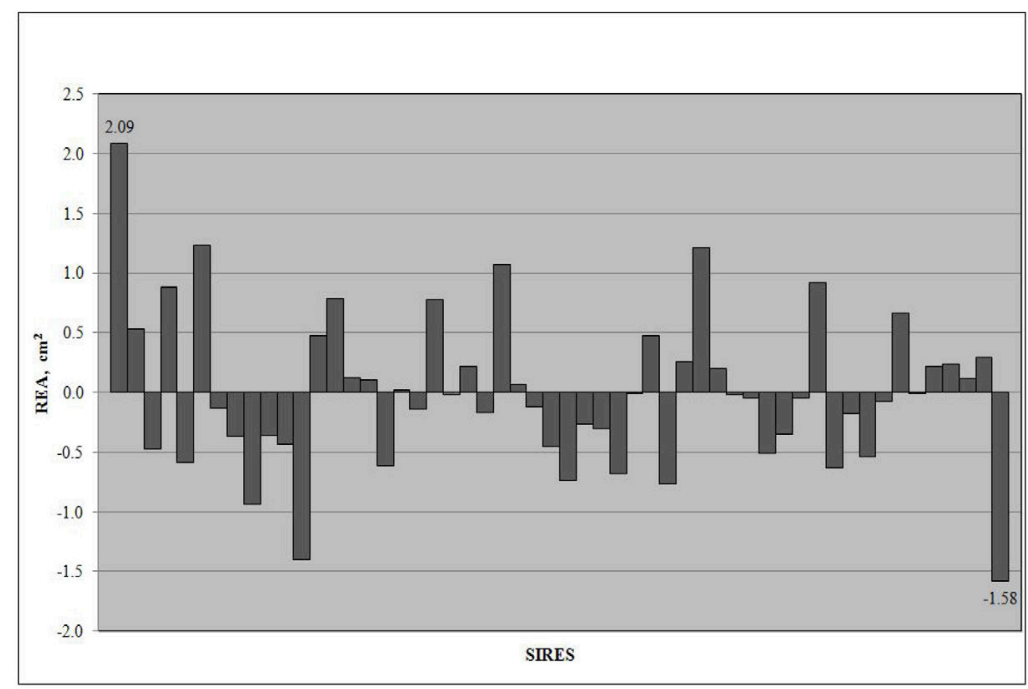

Figure 2. Graphical representation of rib-eye area (REA) values in terms of least square means of sires.

\section{FT and MAR}

We found a sire effect on FT $(\mathrm{P}<0.0001)$ and MAR $(\mathrm{P}=0.0263)$. Some bulls showed positive values of FT and MAR with a difference of approximately $2.5 \mathrm{~mm}$ in FT (Figure 3) and 21 MAR units (Figure 4) between the highest and lowest value found for each of these traits. This shows the existence of variability among Nellore bulls in terms of the transference of FT and MAR grades in the carcass of their progeny; therefore, this information can be included in breeding programs to improve the Nellore beef because they have average heritability coefficients (Marshall, 1994).

FT and MAR play very important roles in consumers' acceptance because they are related to traits such as flavor, juiciness, and visual appearance of the cuts. For the industry, in turn, FT is important to prevent problems such as cold shortening and drip loss. Therefore, these traits are of great relevance to the market. Some slaughterhouses in Brazil, such as the Marfrig Group (www.marfrig.com.br) through quality programs like Nelore Natural, offered a bonus of up to $4 \%$ to producers for animal carcasses with adequate fat cover, among other traits. The use of bulls that provide this fat coverage to the carcass should be encouraged by the Brazilian meat industry through a bonus program to producers because it may result in major advances in the quality and standardization of slaughter batches.

Hocquette et al. (2007) detected variability between B. indicus in terms of the ability of some bulls to improve the transference of intramuscular fat in the carcass of their progeny. Likewise, O'Connor et al. (1997) evaluated carcasses of Nellore and Brahman bulls and concluded that both breeds have the ability to add intramuscular fat in crossbreeding systems. However, when comparing Nellore and Brahman, we have to consider that the Brahman breed was formed from absorbent crosses with B. taurus of British origin, especially the Longhorn and Shorthorn breeds, while the majority of Nellore was obtained from absorbent crosses with B. taurus of Iberian origin (Santiago, 1983), which can influence some of the differ- 
ences between the breeds. King et al. (2006), who evaluated Nellore and Brahman animals in crossbreeding systems with Angus, observed large variations in FT, REA, and MAR grades between families with the same percentage of Zebu heredity, and these variations were higher than the variations found between breeds.

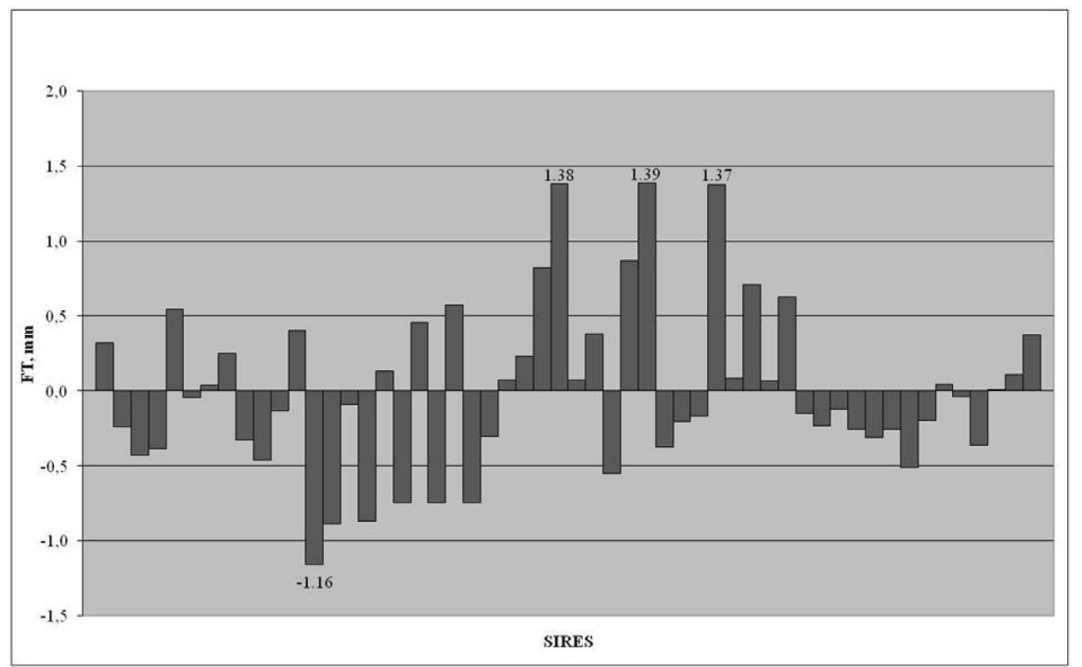

Figure 3. Graphical representation of the values of fat thickness (FT) regarding the least square means of sires.

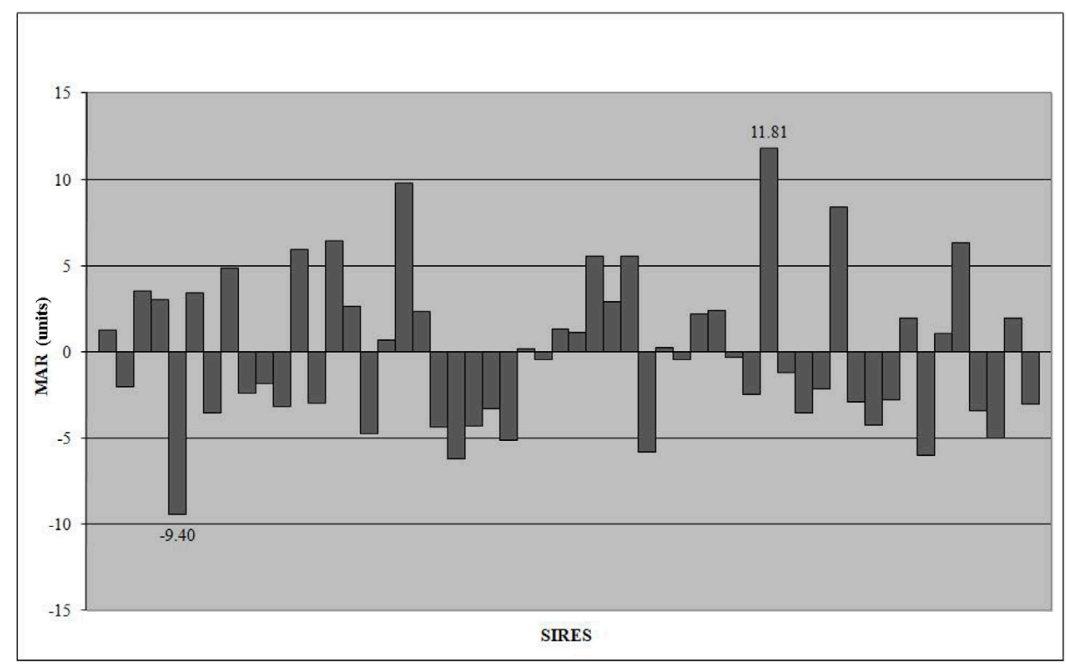

Figure 4. Graphical representation of the values of marbling (MAR) regarding the least square means of sires.

The results of this study show the existence of animals with genetic potential to add FT and MAR to the carcass of their progeny. Thus, the variability in these traits that was found between Nellore animals provides a tool for selecting carcass traits within the breed that can promote significant improvement of carcass and meat quality in Nellore livestock. 


\section{Color}

Variability was found among sires for values of $\mathrm{H}^{*}$ and $\mathrm{L}^{*}$, but not for $\mathrm{C}^{*}(\mathrm{P}>0.05)$, as described in Table 4. Color is an important quality attribute of meat because it acts as one of the most striking factors of consumers' acceptability, primarily on the appearance of the cuts (Insausti et al., 1999). This quality trait can be affected at all stages of the production chain, from the slaughter operations to the cooling and aging stages of the product. Among these factors, animal breed is one of the production parameters that most influenced meat quality and therefore meat color.

Furthermore, some authors attribute the qualitative variations of meat to genetic differences between and within breeds (Liboriussen et al., 1977), suggesting that metabolic differences between animals of the same or different breeds can be considered as important factors of meat coloration that deserve further studies. In this study, variability was observed among sires regarding the ability to produce offspring with different meat colors. For the $\mathrm{L}^{*}$ value, for example, we found some bulls that produced progeny with light meat (Figure 5), which is not desirable. As for $\mathrm{H}^{*}$, we found differences within bulls at 7, 14, and 21 days of aging (Figure 6). Similar to $\mathrm{L}^{*}$, high values of $\mathrm{H}^{*}$ are not desirable because, according Insausti et al. (1999), increases in $\mathrm{H}^{*}$ values correlate negatively $(\mathrm{r}=-0.60)$ with the red color of meat. This is because by increasing $\mathrm{H}^{*}$ values, there is a tendency for an increased prevalence of yellow, green, and blue pigments in the color composition. According to MacDougall (1982), the correlation between $\mathrm{L}^{*}$ and $\mathrm{H}^{*}$ values is 0.77 , indicating that meat with high $\mathrm{L}^{*}$ and $\mathrm{H}^{*}$ values tends to be lighter. Therefore, when selecting bulls for the attribute of meat color, we should seek bulls with intermediate $\mathrm{L}^{*}$ and $\mathrm{H}^{*}$ values, which will ensure the production of progeny with acceptable red meat and, consequently, with greater consumer acceptance.

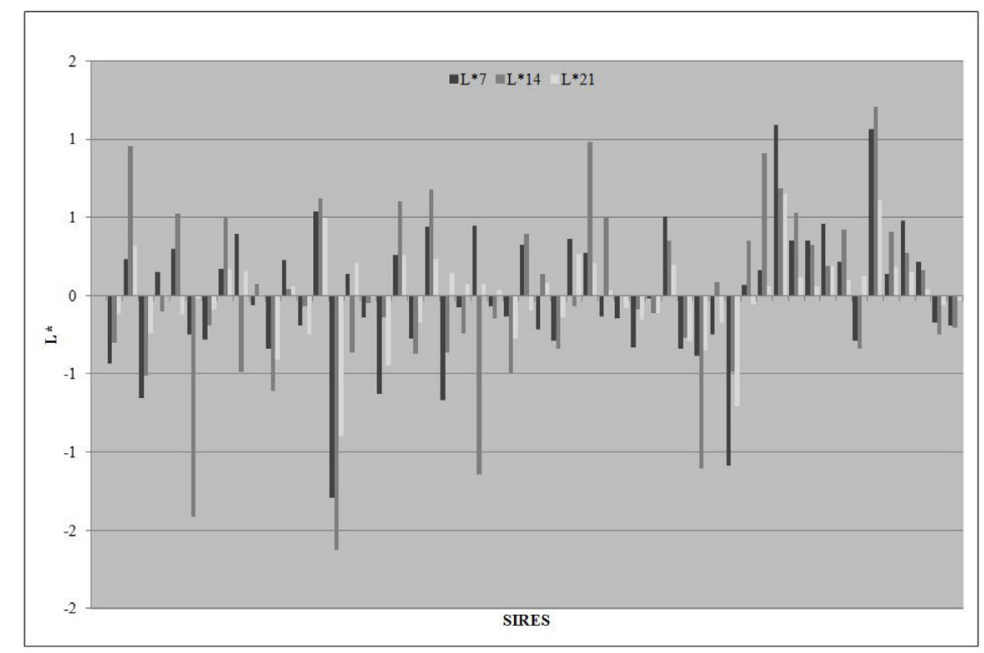

Figure 5. Graphical representation of $L^{*}$ values at 7, 14 and 21 days of aging regarding the least square means of sires.

Thus, the variability found in this study may be explained by genetic and physiological differences among the bulls studied and the possible influence of the handling and slaughtering 


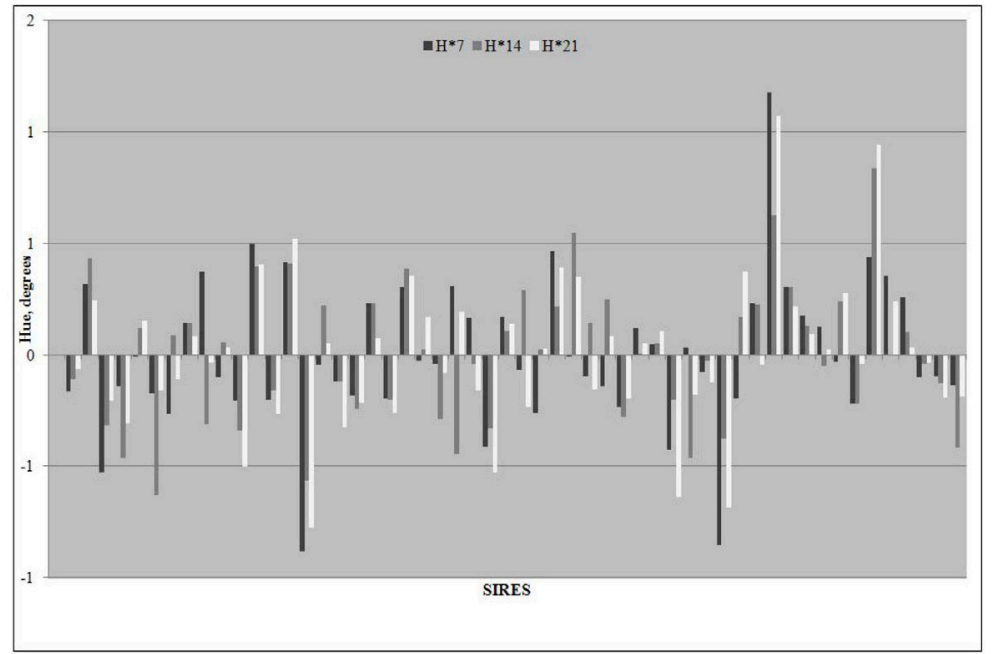

Figure 6. Graphic representation of $\mathrm{H}^{*}$ values at 7, 14 and 21 days of aging regarding the least square means of sires.

procedures because we found effects of slaughter batch and $\mathrm{pH}$ on the color trait. Abril et al. (2001) reported that meat color is highly influenced by the content and nature of myoglobin and by the physical state of the muscle, which is directly related to the final $\mathrm{pH}$ of the meat. Moreover, the decrease in muscle $\mathrm{pH}$, besides exerting a great influence on the activity of calcium-dependent proteases, also seems to act in the oxygenation and oxidation processes of myoglobin. The $\mathrm{pH}$ decrease can also affect the surface color of the meat, making it brighter and moistened, especially in terms of the ability to retain water in the muscle, thereby influencing the color grades relating to brightness, such as $\mathrm{L}^{*}$ and $\mathrm{H}^{*}$ values (Swatland, 1989). Therefore, the variability in meat color of different progenies of Nellore bulls may be attributed to genetic factors that are closely related to the animal metabolism and $\mathrm{pH}$, which can also act as a relevant factor that has great importance in determining the myoglobin state and the waterholding capacity of the muscle, which is related to the meat surface brightness.

\section{SF}

There was no sire effect on SF values in any aging period $(\mathrm{P}>0.05)$. Although no effect was detected, we observed an oscillation in SF during different periods of aging in the graphical representation of the variance components of SF values (Figures 7, 8, and 9). At 7 days of aging, we found a difference of $0.48 \mathrm{~kg}$ between bulls that had the lowest and highest $\mathrm{SF}$ values (Figure 7). At 14 days of aging, the difference was even greater, reaching $0.57 \mathrm{~kg}$ (Figure 8), and it reduced to $0.46 \mathrm{~kg}$ at 21 days of aging (Figure 9). Although they seem like minor differences, they have great genetic significance because they indicate that the genetic selection of animals within a breed can lead to the reproductive choice of producing progeny with more tender meat. In addition, when combined with other factors such as pre- and postslaughter handling procedures, the differences may help in the production of more tender meat. Over the aging process, we found a change in the proportion of tender meat $(\mathrm{SF}<4.5$ $\mathrm{kg}$ ), from $15.2 \%$ of animals at 7 days of aging to $57.8 \%$ at 21 days of aging (Figure 10). 


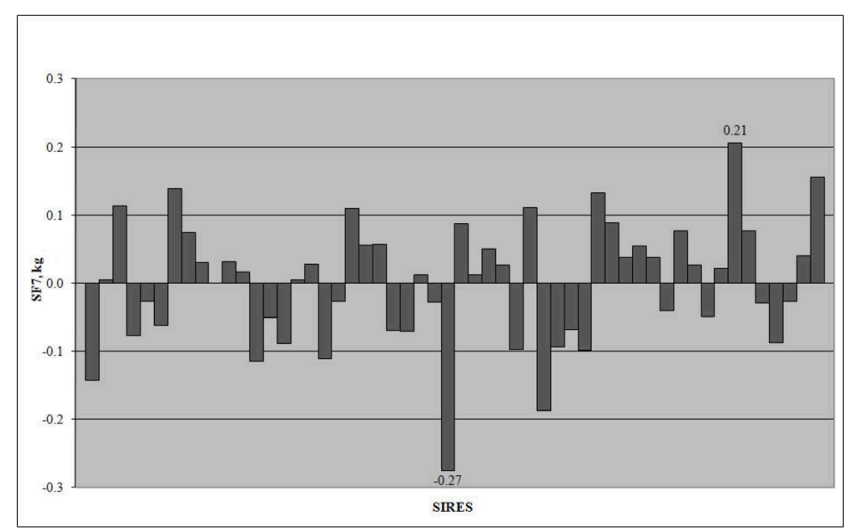

Figure 7. Graphical representation of shear force values at 7 days of aging (SF7), regarding the least square means of sires.

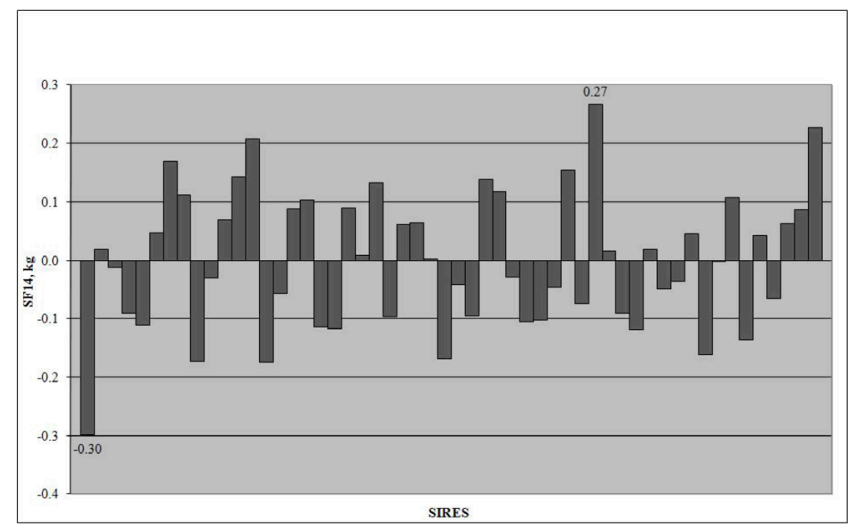

Figure 8. Graphical representation of shear force values, at 14 days of aging (SF14), regarding the least square means of sires.

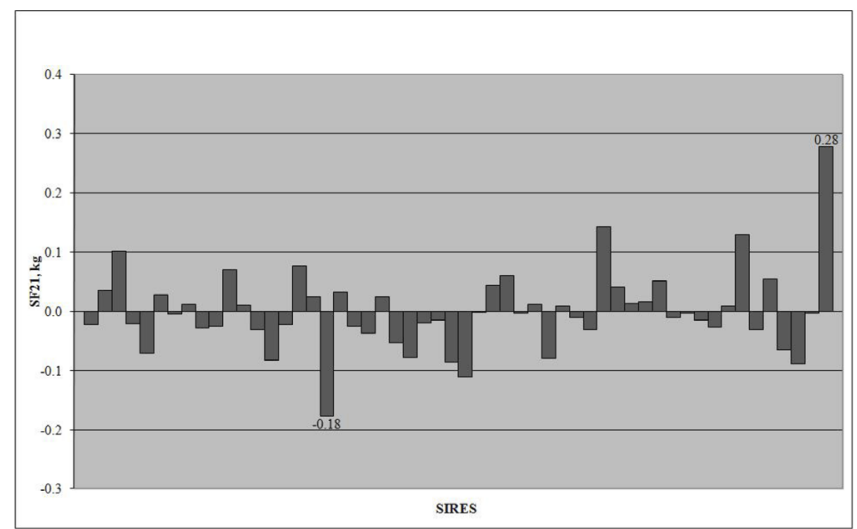

Figure 9. Graphical representation of shear force values at 21 days of aging (SF21), regarding the least square means of sires. 


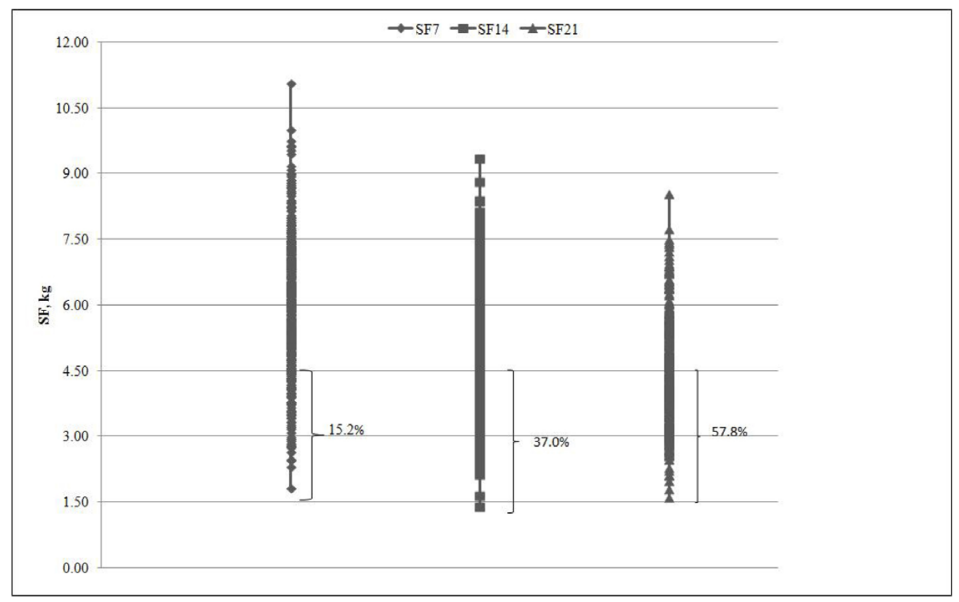

Figure 10. Proportion of meat considered tender $(\mathrm{SF}<4.5 \mathrm{~kg})$ over maturation periods.

The sources and variation types in SF are related to several factors including bull effect, termination, contemporary group, and slaughter batch (Robinson et al., 2001). According to the authors, in breeds that are adapted to tropical climates, such as B. indicus, the bull effect is the third largest source of variation in longissimus tenderness, after the effect of contemporary group and breed. The authors emphasize the importance of controlling pre- and post-slaughter conditions to prevent adverse effects to the animal's genetic heritage, allowing the actual value of this genetic trait and its likely market value to be obtained. In this study, we found a linear relationship between $\mathrm{pH}$ and SF values at 7 days of aging. The $\mathrm{pH}$ influence on qualitative factors of meat has been widely investigated by many authors, especially relative to the activity of proteolytic enzymes that act in meat tenderization (Dransfield, 1994).

Changes in the proportion of tender meat during the aging period can be explained by the activity of proteolytic enzymes during storage. As described by Dransfield (1994), the process of meat tenderization begins when $\mu$-calpain is activated about $6 \mathrm{~h}$ after slaughter. The process is complemented by the activation of $\mu$-calpain $16 \mathrm{~h}$ after slaughter; about $50 \%$ of meat tenderization seems to occur before $24 \mathrm{~h}$ after slaughter and can reach $90 \%$ or more of its total tenderization with 7 to 10 days of post-mortem storage. Some authors suggest, however, that greater than $80 \%$ of the enzymatic activity that is measured at slaughter could remain for longer than 14 days of storage (Koohmaraie et al., 1987). Whipple et al. (1989) evaluated differences in meat tenderness between B. taurus and B. indicus, such as Nellore, and found that calpastatin activity in crossings with B. taurus had lost $65 \%$ of its activity on the first post-mortem day, whereas there was a minor loss of enzymatic activity in crossings with $B$. indicus in the same period (40 to $44 \%$ ). This suggests a higher calpastatin activity in the first post-mortem days in animals with a higher percentage of $B$. indicus genetic heredity, placing calpastatin as an important predictor of longissimus tenderness (Whipple et al., 1990).

Smith et al. (2003) believed that calpain and calpastatin were not sufficient to detect genetic variations of tenderness among animals of the same breed, given that other muscle components such as sarcomere length and connective tissue are important in determining this trait. This suggests that the control of these genetic factors should also be included in breeding programs for tenderness. Therefore, we can assume that when trying to detect the sire 
effect on meat tenderness at 7, 14, and 21 days of aging, we were analyzing different ranges or stages of calpain and calpastatin activity. This is also the most likely reason for changes in the proportion of tender meats during the aging periods as shown in Figure 10. However, the activities of calcium-dependent proteases were not evaluated, leaving only assumptions about their roles in the muscle tenderizing process and the variability of the proteolytic activity in the Nellore breed. Although the differences were not statistically significant, there are important differences among bulls, which suggests that there is a genetic influence on this trait, indicating that further studies with a greater number of observations should be conducted in the Nellore breed.

\section{CONCLUSION}

Variability among Nellore bulls produces progeny with high carcass and meat qualities. Information about HCW and REA may be used in Nellore breeding programs to increase the weight and amount of muscles, especially prime cuts, of the carcass. The use of Nellore bulls with high genetic values for the transfer of intramuscular and FT in breeding programs of beef cattle can bring significant advances in the meat quality of Nellore animals and, consequently, the Brazilian beef. Finally, it is proposed that further studies be conducted to verify the variability in Nellore bulls for the production of tender meat, especially investigating the activity of proteolytic enzymes at different aging periods.

\section{ACKNOWLEDGMENTS}

We wish to thank the Scientific Research Foundation of Ribeirão Preto (FUNPEC$\mathrm{RP}$ ) for the financial support to carry out this research and Agro-Pecuária CFM Ltda. for supplying the animals.

\section{REFERENCES}

Abril M, Campo MM, Onenc A, Sanudo C, et al. (2001). Beef colour evolution as a function of ultimate pH. Meat Sci. 58: 69-78.

American Meat Science Association (AMSA) (1995). Research Guidelines for Cookery, Sensory Evaluation, and Instrumental Tenderness Measurements of Meat. 1st edn. American Meat Science Association, Chicago.

Associação Brasileira das Indústrias Exportadoras de Carne (ABIEC) (2012). Rebanho Bovino Brasileiro. Available at [http://www.abiec.com.br/3_rebanho.asp]. Accessed May 3, 2012.

Burrow HM, Moore SS, Johnston DJ, Barendse W, et al. (2001). Quantitative and molecular genetic influences on properties of beef: a review. Aust. J. Exp. Agr. 41: 893-919.

Diário Oficial da República Federativa do Brasil (DORFB) (1995). Portaria No. 267, de 4 de Maio de 1995. Poder Executivo, Brasília, DF, 5 de Maio de 2005. Seção 1, 6409.

Dransfield E (1994). Optimisation of tenderisation, ageing and tenderness. Meat Sci. 36: 105-121.

Ferraz JB and Felício PE (2010). Production systems - an example from Brazil. Meat Sci. 84: 238-243.

Hamlin KE, Green RD, Cundiff LV, Wheeler TL, et al. (1995). Real-time ultrasonic measurement of fat thickness and longissimus muscle area: II. Relationship between real-time ultrasound measures and carcass retail yield. J. Anim. Sci. 73: 1725-1734.

Hocquette JF, Lehnert S, Barendse W, Cassar-Malek I, et al. (2007). Recent advances in cattle functional genomics and their application to beef quality. Animal 1: 159-173.

Hunt MC, Acton JC, Benedict RC, Calkins CR, et al. (1991). Guideliness for Meat Color Evaluation. In: Proceedings of the $44^{\circ}$ Reciprocal Meat Conference, Chicago.

Insausti K, Beriain MJ, Purroy A, Alberti P, et al. (1999). Colour stability of beef from different Spanish native cattle breeds stored under vacuum and modified atmosphere. Meat Sci. 53: 241-249. 
Instituto Brasileiro de Geografia Estatística (IBGE) (2012). Número de Animais Abatidos. Available at [http://www.sidra. ibge.gov.br/bda/tabela/protabl.asp?c=1092\&z=t\&o=24\&i=P]. Accessed May 3, 2012.

Kastner CL and Henrickson RL (1969). Providing uniform meat cores for mechanical shear force measurement. J. Food Sci. 34: 603-605.

King DA, Morgan WW, Miller RK, Sanders JO, et al. (2006). Carcass merit between and among family groups of Bos indicus crossbred steers and heifers. Meat Sci. 72: 496-502.

Koohmaraie M (1996). Biochemical factors regulating the toughening and tenderization processes of meat. Meat Sci. 43S1: 193-201.

Koohmaraie M, Seidemann SC, Schollmeyer JE, Dutson TR, et al. (1987). Effect of post-mortem storage on $\mathrm{Ca}^{2+}-$ dependent proteases, their inhibitor and myofibril fragmentation. Meat Sci. 19: 187-196.

Liboriussen T, Andersen B, Buchter L, Kousgaard K, et al. (1977). Crossbreeding experiment with beef and dual-purpose sire breeds on Danish dairy cows IV. Physical, chemical and palatability characteristics of longissimus dorsi and semitendinosus muscles from crossbred young bulls. Livest. Prod. Sci. 4: 31-43.

MacDougall DB (1982). Changes in colour and opacity of meat. Food Chem. 9: 75-88.

Marshall DM (1994). Breed differences and genetic parameters for body composition traits in beef cattle. J. Anim. Sci. 72: $2745-2755$

O'Connor SF, Tatum JD, Wulf DM, Green RD, et al. (1997). Genetic effects on beef tenderness in Bos indicus composite and Bos taurus cattle. J. Anim. Sci. 75: 1822-1830.

Robinson DL, Ferguson DM, Oddy VH, Perry D, et al. (2001). Genetic and environmental influences on beef tenderness. Aust. J. Exp. Agr. 41: 997-1003.

Sainz RD, Magnabosco CU and Manicardi F (2005). Projeto OB-Choice: Genética para Melhorar a Qualidade da Carne Brasileira. In: $3^{\circ}$ Seminário da Marca OB, Cuiabá.

Santiago AA (1983). O Nelore. Editora dos Criadores, São Paulo.

SAS Institute Inc. (2003). SAS/STAT User’s Guide: Release 9.1. 3rd edn. SAS Institute, Inc., Cary.

Smith TPL, Thallman RM, Casas E, Shackelford SD, et al. (2003). Theory and application of genome-based approaches to improve the quality and value of beef. Outlook Agr. 32: 253-265.

Swatland HJ (1989). A review of meat spectrophotometry (300 to 800 nm). Can. Inst. Food Sci. Technol. J. 22: 390-402.

United States Department of Agriculture (USDA) (2011). PSD Online - Custom Query. Available at [http://www.fas.usda. gov/psdonline/psdquery.aspx]. Accessed October 5, 2011.

Van Vleck LD, Hakim AF, Cundiff LV, Koch RM, et al. (1992). Estimated breeding values for meat characteristics of crossbred cattle with an animal model. J. Anim. Sci. 70: 363-371.

Wheeler TL, Savell JW, Cross HR, Lunt DK, et al. (1990). Mechanisms associated with the variation in tenderness of meat from Brahman and Hereford cattle. J. Anim. Sci. 68: 4206-4220.

Whipple G, Koohmaraie M, Dikeman ME and Crouse JD (1989). A comparison of Bus indicus and Bos taurus breeds. II. Calcium dependent protease CDP and catheptic enzyme proteolytic activity. J. Dairy Sci. 72 (Suppl 1): 180.

Whipple G, Koohmaraie M, Dikeman ME, Crouse JD, et al. (1990). Evaluation of attributes that affect longissimus muscle tenderness in Bos taurus and Bos indicus cattle. J. Anim. Sci. 68: 2716-2728. 